\title{
The Impact of Company Characteristics on Derivatives Usage: Survey Study of Large Croatian Companies
}

\author{
Ivana Štulec, Spec.M.Sc.Econ. \\ Teaching and Research Assistant \\ Faculty of Economics and Business, University of Zagreb \\ Trg J.F. Kennedyja 6, 10000 Zagreb, Croatia \\ istulec@efzg.hr \\ Tomislav Baković, Ph.D. \\ Assistant Professor \\ Faculty of Economics and Business, University of Zagreb \\ Trg J.F. Kennedyja 6, 10000 Zagreb, Croatia \\ tbakovic@efzg.hr \\ Ines Dužević, Ph.D. \\ Teaching and Research Assistant \\ Faculty of Economics and Business, University of Zagreb \\ Trg J.F. Kennedyja 6, 10000 Zagreb, Croatia \\ iduzevic@efzg.hr
}

\section{Doi:10.5901/mjss.2013.v4n10p59}

\section{Abstract}

The use of derivatives for risk management purposes has been a worldwide phenomenon for several decades. Researches show that use of derivatives as a tool of corporate risk management can contribute to the creation of company's market value and shareholder wealth. Studies on companies' motives for derivatives usage and non-usage were conducted in USA, Canada, Australia, United Kingdom, Belgium, Sweden, Taiwan and Pakistan. In the recent years, the subject of derivatives markets has been abundantly covered in Croatian literature as well. At the moment, there is no derivatives market in Croatia, and only viable exchange trading is spot trading of securities on the Zagreb Stock Exchange. However, those interested can trade at major European and world exchanges through mediation of domestic and foreign brokers. For this reason, the attitude of Croatian companies towards derivatives trading imposed as insufficiently studied area of research. For the purpose of this paper a primary research was conducted among large Croatian companies. The purpose of the research was to determine the extent to which large Croatian companies are familiar with the concept and strategies of derivatives trading, how many companies use derivatives, the type of most commonly used derivatives and motives for use and non-use of derivatives among Croatian companies. The analysis of survey results was conducted through cross-tabulation in order to assess the impact of company characteristics on derivatives usage.

Keywords: hedging, risk management, derivatives, large companies, Croatia.

\section{Introduction}

Even though trading of goods with delivery into the future has been present for several centuries now, trading of derivatives still remains one of the most sophisticated forms of modern corporate risk management. Derivative is financial instrument or security whose value is dependent on value of some other fundamental good or underlying asset. Derivative contracts involve exchange of one asset for another and are initiated at one time, while performance in accordance with the terms of contracts occurs at a subsequent time (Kolb, 2003). For example, a gold derivative is an agreement between a buyer and a seller on the exchange of gold at a fixed date in the future, called the contract's expiry or maturity date, at a price agreed at a time of initial contracting while the actual payment and delivery of gold occur later in the future.

Nowadays, trading in derivatives takes place mostly on the organized exchanges in the form of futures contracts. Futures 
contracts are highly standardized derivative contracts with the quantity and quality of underlying asset, form of price quotation and method of final delivery or settlement clearly defined by the contract specification. Alternative to institutional trade on organized exchange is the over-the-counter trade in the form of forwards and swaps as privately negotiated agreements. Trading in futures requires margin deposit. Margin is the amount of money or other highly liquid asset which has to be paid by the prospective traders in order to indicate their ability to fulfil their financial obligations arising from trading futures (Orsag, 2006). Due to the margin deposits, performance on futures contracts is guaranteed by the clearinghouse, meaning that trading in futures virtually eliminates credit risk i.e. risk of default. On the other hand, trading in forwards is self-regulated and can expose traders to great amount of credit risk. However, forwards provide traders with benefit of customized risk management solutions. Futures trading emerged from forwards trading.

There are four basic strategies of trading at derivatives markets: speculation, hedging, arbitrage and trading options (Lazibat et al., 2007). A speculator is a trader who enters the futures market in search of profit and, by doing so, willingly accepts risk. Because of this, speculators are often mentioned in a negative context, although their presence is necessary for futures market liquidity. In contrast to a speculator, the hedger is a trader who enters the futures market in order to reduce a pre-existing risk. An example of a hedger is a subject who needs to buy or sell certain goods in the future, such as a farmer or a food producer, and whose future business performance is reflected by price changes of related goods. A hedge is performed by taking a position in the futures market that is opposite to the risk exposed position in the cash market. Arbitrage is a riskless futures trading strategy and arbitrageur simultaneously buys and sells certain good given that price spread is large enough to cover all the transaction costs. Fourth trading strategy is trading options. Options on futures contracts give option buyers the right, but not the obligation to buy or sell an underlying futures contract at a predetermined fixed price, called strike or exercise price, until maturity date. For such right, option buyer pays option seller a premium (Lazibat \& Matić, 2001). There are two basic types of options; a call options that gives the buyer the right to buy an underlying futures and a put option that gives a buyer the right to sell an underlying futures. The major advantage of options over futures contracts is that buyer's maximum loss is limited to the amount of premium. If the futures prices move in the unfavourable direction, the option buyer can decide not to exercise the option and all he loses is prepaid option premium (Lazibat, 2000). It can be concluded that the most important function of futures markets is to allow the price risk transfer from the subjects who wish not or cannot accept it to the subjects who consciously and willingly accept it in order to gain profit, i.e. from hedgers to speculators.

The use of derivatives for risk management purposes has been a worldwide phenomenon for several decades. Mseddi \& Abid (2010) argue that use of derivatives as a tool of corporate risk management can contribute to the creation of company's market value and shareholder wealth. The purpose of risk management activities is to ensure the best possible combination of return and certainty of achieving that return with respect to the company's resources and risk preferences. Deviation from the planned revenues or cash flows may weaken company's financial state and lead to harder access to external capital at higher rates (Schultz, 1996). Reducing the volatility of cash flows, companies can decrease costs of financial distress and obtain internal funds for financing new investments, as well as reduce the dependence on costly external capital (Bartram, 2000).

At the moment, there is no derivatives market in Croatia, and only viable exchange trading is spot trading of securities on the Zagreb Stock Exchange. However, those interested can trade at major European and world exchanges through mediation of domestic and foreign brokers. For this reason, the attitude of Croatian companies towards derivatives trading imposed as insufficiently studied area of research. For the purpose of this paper a primary research was conducted among large Croatian companies. The purpose of the research was to determine the extent to which large Croatian companies are familiar with the concept and strategies of derivatives trading, how many companies use derivatives and how they evaluate the usefulness of derivatives usage. Further was explored which type of derivatives are most commonly used by Croatian companies and reasons why Croatian companies choose not to use derivatives. The analysis of survey results was performed through cross-tabulation of results as to assess the impact of company characteristics on derivatives usage.

The rest of the paper is organized as follows. After introduction, next section gives a literature review of studies on derivatives usage. Third section describes the design of conducted empirical research. Fourth section presents characteristics of surveyed sample and results analysis. Fifth section concludes.

\section{Literature review on derivatives usage}

Bodnar et al. $(1998,2003)$ provided a detailed description of derivative usage, motives for usage and non-usage, exposures and concerns of the U.S. companies. In a number of recent survey studies, additional countries have been 
studied, such as Australia (Nguyen \& Faff, 2002; Heaney \& Winata, 2005), United Kingdom (Grant \& Marshall, 1997; ElMasry, 2006), Belgium (De Ceuster et al., 2000), Sweden (Alkebäck et al., 2006), Pakistan (Afza \& Alam, 2011) and Taiwan (Shu \& Chen, 2003). Jalilvand et al. (2000) compared the use of derivatives between Canadian, U.S. and European companies, and Bodnar et al. (2003) between U.S. and Dutch companies.

In the recent years, the subject of derivatives trading has been abundantly covered among Croatian researchers as well. However, the majority of papers deal with the conceptual framework of derivatives, while only some smaller number of authors conducted an empirical research on derivatives trading among Croatian companies. Lazibat (2000), Lazibat \& Matić (2001), Uran (2007), Lazibat \& Baković (2007), Šperanda (2008, 2009), Lazibat et al. (2009, 2011) and Gardijan (2011) discussed the instruments of derivatives markets and possible trading strategies. Slakoper \& Štajfer (2007) discussed the legal aspect of option contracts. Dedi (2004), Posedel (2006) and Božić (2010) studied the option valuation techniques. Some smaller number of domestic authors conducted an empirical research on derivatives usage among Croatian companies. Miloš Sprčić (2007a), Miloš Sprčić \& Šević (2008), Miloš Sprčić et al. (2008) and Sučić et al. (2011) studied the use of derivatives among Croatian companies as a mean of corporate risk management, whereas Lazibat et al. (2007) and Baković et al. (2012) studied the use of derivatives among Croatian companies in general, including both hedging and speculative motivation of derivative traders. Miloš Sprčić (2007b) compared the derivatives usage among Croatian and Slovenian companies. The value of research conducted for the purpose of this paper is that it explores whether company characteristics, and in what way, affect derivatives usage among large Croatian companies.

Results of previous studies show that large number of companies uses derivatives, regardless of a country of origin. For example, $44 \%$ of surveyed companies in U.S. and $60 \%$ in Netherlands (Bodnar et al., 2003), $57 \%$ of surveyed companies in Croatia (Miloš Sprčić et al., 2008; Sučić et al., 2011), 59\% of surveyed companies in Sweden (Alkebäck et al., 2006), 65\% of surveyed companies in Australia (Heaney \& Winata, 2005) and Belgium (De Ceuster et al., 2000) and $66 \%$ of surveyed companies in Slovenia (Miloš Sprčić, 2007b) use derivatives. Results of studies are not directly comparable as characteristics of surveyed sample differ between countries. Nevertheless, results give good insight into degree of development of financial markets in given countries.

Some authors conducted longitudinal comparable studies on derivatives usage the results of which indicate the trends on financial markets in given countries. The share of companies that use derivatives remained somewhat constant in U.S. (Bodnar et al., 1998) and Croatia (Miloš Sprčić et al., 2008; Sučić et al., 2011) and slightly increased from $52 \%$ in 1996 to 59\% in 2003 in Sweden (Alkebäck et al., 2006). On the other hand, in the recent years a growing number of companies in Croatia became aware of the importance of risk management. In 2006, 73\% of large non-financial companies in Croatia managed at least one type of financial risk (Miloš Sprčić et al., 2008), whereas in 2011 the share of large non-financial companies that manage financial risks rose to 93\% (Sučić et al., 2011). It can be concluded that even though companies in countries with underdeveloped financial markets began to realize financial risks, they still do not acknowledge the benefits of derivatives as hedging instruments. Hence, further education on derivatives market is needed.

Studies show that large companies are the dominant users of derivatives (Nguyen \& Faff, 2002; Bodnar et al., 2003; Alkebäck et al., 2006; El-Masry, 2006), so it can be concluded that company size is the primary characteristic distinguishing users from non-users of derivatives. Such results are reasonable given that larger companies are exposed to a greater range of risks and that derivative trading entails high fixed costs associated with transaction start up. Economic activity of company also affects the extent of derivatives usage. Excluding financial firms, results of Bodnar et al. (1998) show that use of derivatives is higher among primary product companies and manufacturers than among companies in the service industry. However, the intensity of use of derivatives by service companies is increasing significantly faster than for other companies.

The results of Nguyen and Faff (2002) show that leverage (as proxy for financial distress costs), firm size (financial distress and setup costs) and liquidity (as proxy for financial constraints in the underinvestment hypothesis) are the most important factors influencing the likelihood that company will use derivatives.

Companies, regardless of a size or economic sector, mainly use derivatives for hedging purposes striving to achieve lower earnings volatility. On the other hand, the use of derivatives for speculative and arbitrage purposes is concentrated to large companies (Alkebäck et al., 2006). Companies benefit from hedging by reducing the volatility of earnings and cash flows, decreasing thus specific costs such as bankruptcy costs, expected taxes and agency costs, which in turn increases firm value. Focusing on stabilizing recorded earnings and cash flows, companies manage stakeholders' perception about company and thus its market value. Beside earnings volatility reduction, De Ceuster et al. (2000) mention locking in profits and reducing costs of funds as major motives for using derivatives as hedging instruments. 
Derivatives are dominantly used as hedge against foreign exchange and interest rate risk, whereas only some smaller share of companies uses derivatives as hedge against commodity price risk (Bodnar et al., 1998; Jalilvand et al., 2000; Hguyen \& Faff, 2002; Alkebäck et al., 2006). Regarding the type of derivatives, most commonly used are forwards, swaps and options and such results prevail for countries with well-developed derivatives market such as Belgium (De Ceuster et al., 2000), as well as for countries with underdeveloped derivatives market such as Croatia (Miloš Sprčić et al., 2008; Sučić et al., 2011). Swaps prove to be dominant derivative type used as hedge against interest rate risk and forwards as hedge against foreign currency risk, both in developed Belgian market (De Ceuster et al., 2000) and underdeveloped Croatian market (Sučić et al., 2011). Derivatives types traded on organized exchanges, such as futures, are rarely used on both Croatian and Belgian markets. Further on, results of Sučić et al. (2011) show that majority of companies exposed to financial risks rely on natural hedging by managing assets and liabilities, which can be explained with the fact that there is no organized derivatives exchange in Croatia and lack of knowledge about derivatives market among Croatian managers. Lack of awareness of the benefits that result from using derivatives may lead companies to lose out in the gains and protection that derivatives offer when carefully handled.

The most important reasons why Croatian companies do not use derivatives as risk management instruments are insufficient supply of risk management instruments offered by Croatian financial industry, high costs of establishing and maintaining risk management programs and difficulties in pricing and valuation of derivatives (Miloš Sprčić et al., 2008). Belgian companies mention policy restrictions imposed by board of directors, perceived risk of derivatives, insignificance of company's exposure to financial risks and existence of other hedging instruments as main reasons for not using derivatives (De Ceuster et al., 2000).

\section{Design of research}

Empirical research on the use of derivatives among Croatian companies lasted for five weeks and was conducted during May and June in 2012. The survey was conducted using an online questionnaire as a research instrument. Large companies were selected as a population of interest because former studies of Nguyen \& Faff (2002), Bodnar et al. (2003), Alkebäck et al. (2006) and El-Masry (2006) show that large companies, compared to small and medium companies, tend to use derivatives to an larger extent. Large companies were classified in accordance with the Croatian Accounting Act (Narodne novine, no. 109/2007). Register of Business Entities of the Croatian Chamber of Commerce was used for list of companies that meet the size criteria. Only companies that have submitted annual financial report in 2011 were included as to assure that active companies are surveyed. According to the Register, there are 360 active large companies in Croatia. The questionnaire consisted of 19 questions, of which 8 general about company characteristics and 11 specific about derivatives usage. The questionnaire was constructed as a mixture of close-ended, open-ended and rating scale questions. To ensure the maximum rate of return, every week new reminders on research were sent out. During the specified time period, 32 companies fulfilled the questionnaire, which resulted in rate of return of $8.9 \%$ of total number of large active companies in Croatia. Respondents were mainly Board members and Directors of Finance or Accounting Departments.

\section{Research results}

\subsection{Sample characteristics}

Table 1 shows characteristic of companies in the sample. Majority of companies in the sample are from the manufacturing sector, legally established as a public limited company, privately owned and with dominantly domestic sources of capital. According to the total income earned in 2011, majority of companies belong to the 100 to 500 million HRK category ( 1 EUR $\approx 7.5$ HRK). Regarding the educational structure within the company, an equal number of companies in the sample have less than $50 \%$ and more than $80 \%$ of top managers with a university degree.

\subsection{Knowledge about and usage of derivatives among Croatian companies}

The respondents were asked to assess on a scale 1 to 5 their knowledge about derivatives trading strategies and results show highest familiarity with hedging strategy (Mean=2.97), followed by speculations (Mean= 2.93), options (Mean= 2.83) and arbitrage (Mean=2.50). Given that all assessments of familiarity are lower than 3.0 it can be concluded that Croatian companies have poor knowledge of derivatives market and trading strategies. The majority of respondents 
learned about derivatives through formal university education (52.4\%) and further education at workplace (28.6\%). As other sources of information on derivatives, respondents mention seminars, business contacts and media. Only seven companies actually use derivatives (21.9\%), which is rather small share compared to the results of Miloš Sprčić et al. (2008) and Sučić et al. (2011). Forward contracts are the most commonly used derivatives type, which is reasonable given that there is no organized derivatives exchange in Croatia. Majority of companies hedge against foreign currency risk. All respondents whose companies use derivatives, mention hedging as primary purpose of derivatives usage. None of the companies use derivatives with the aim of conscious risk taking and achieving speculative gains. Hence, it is not surprise that hedging is the trading strategy that respondents are most familiar with. Moreover, respondents perceive hedging as the most important derivatives trading strategy for the company profitability and the one that results with greatest benefits. Insight that some Croatian companies use derivatives for more than a decade acts as a confirmation that proper use of derivatives results with substantial benefits. More than $70 \%$ of respondents believe that derivatives will become inevitable risk management tool for Croatian companies in next 10 years.

Table 1. Sample characteristics

\begin{tabular}{|lcc|}
\hline Economic activity according to National Classification of Activities 2007 & $\%$ & No. \\
\hline Agriculture, forestry and fishing (A) & $3,1 \%$ & 1 \\
Manufacturing industry (C) & $34,4 \%$ & 11 \\
Water supply, sewerage, waste management and remediation activities (E) & $3,1 \%$ & 1 \\
Construction (F) & $9,4 \%$ & 3 \\
Wholesale and retail trade, repair of motor vehicles and motorcycles (G) & $9,4 \%$ & 3 \\
Transportation and storage (H) & $6,3 \%$ & 2 \\
Accommodation and food service activities (I) & $6,3 \%$ & 2 \\
Information and communication (J) & $3,1 \%$ & 1 \\
Financial and insurance activities (K) & $12,5 \%$ & 4 \\
Other & $12,5 \%$ & 4 \\
\hline Legal organizational form & & \\
\hline Public limited company & $62,5 \%$ & 20 \\
Private limited company & $37,5 \%$ & 12 \\
\hline Form of ownership & & \\
\hline Private & $74,2 \%$ & 23 \\
State/community & $19,3 \%$ & 7 \\
Mixed & $6,5 \%$ & 2 \\
\hline Origin of capital & & \\
\hline Domestic & $75,0 \%$ & 24 \\
Foreign & $15,6 \%$ & 5 \\
Mixed & $9,4 \%$ & 3 \\
\hline Total income in 2011 & & \\
\hline Less than 100 million HRK & $29,0 \%$ & 9 \\
100 to 500 million HRK & $38,7 \%$ & 12 \\
500 million to 1 billion HRK & $22,6 \%$ & 7 \\
More than 1 billion HRK & $9,7 \%$ & 3 \\
\hline Share of top managers with university degree & & \\
\hline Less than 50\% & $43,8 \%$ & 14 \\
50 to 80\% & $12,5 \%$ & 4 \\
More than 80\% & $43,8 \%$ & 14 \\
\hline
\end{tabular}

Respondents that stated that their companies do not use derivatives were asked to assess the importance of reasons for not using derivatives. Results show that insufficient knowledge about derivatives, perception of derivatives as risky investments and insufficient support of top management act as most important obstacles that hinder more widespread use of derivatives among large Croatian companies. 


\subsection{Impact of company characteristics on derivatives usage among Croatian companies}

The survey results were cross-tabulated in order to explore association between company characteristics and derivatives usage. First, association between economic sector and derivatives usage was explored. Companies were divided into four economic sectors according to the economic activity they are engaged in. Primary economic sector included Agriculture, forestry and fishing (A). Secondary economic sector included Manufacturing industry (C), Water supply, sewerage, waste management and remediation activities (E) and Construction (F). Tertiary economic sector included Wholesale and retail trade, repair of motor vehicles and motorcycles $(G)$, Transportation and storage $(H)$, Accommodation and food service activities (I), Information and communication (J) and Financial and insurance activities (K). Quaternary economic sector included other economic activities. Results are presented in Table 2. It can be seen that primary sector is only economic sector that has more derivatives users than non-users, so it can be concluded that economic activity has impact on derivatives usage. Such results can be explained by the fact that primary sector includes the production of raw materials and food from natural resources, resulting in higher exposure to risk of unfavourable commodity price movements and foreign currency risk if companies are operating internationally.

Table 2. Association between economic sector and derivatives usage

\begin{tabular}{|c|c|c|}
\hline Economic sector & Derivatives users & Derivatives non-users \\
\hline Primary & $100.0 \%$ & $0.0 \%$ \\
\hline Secondary & $22.2 \%$ & $77.8 \%$ \\
\hline Tertiary & $37.5 \%$ & $62.5 \%$ \\
\hline Quaternary & $25.0 \%$ & $75.0 \%$ \\
\hline
\end{tabular}

Next, association between legal organizational form and derivatives usage was examined. It can be assumed that public limited companies use derivatives to a greater extent than other organizational form of companies, as they need to manage public perception and maximize shareholders' wealth. Results are presented in Table 3. It can be noticed that greater share of public limited companies than private limited companies uses derivatives, as it was expected, so it can be concluded that legal organizational form impacts derivatives usage. However, given that difference is rather small, results should be taken with caution.

Table 3. Association between legal organizational form and derivatives usage

\begin{tabular}{|c|c|c|}
\hline Legal organizational form & Derivatives users & Derivatives non-users \\
\hline Public limited company & $35.7 \%$ & $64.3 \%$ \\
\hline Private limited company & $25.0 \%$ & $75.0 \%$ \\
\hline
\end{tabular}

Table 4 presents the results of examination of association between form of ownership and derivatives usage. It was assumed that private companies use derivatives to a greater extent, compared to other forms of ownership, since they are fully dependent on market movements and cannot pass costs of unexpected unfavourable events on tax payers. The results regarding the impact of form of ownership are quite unexpected. Companies owned by state show the greatest share of derivatives users, compared to privately owned companies and companies of mixed ownership. One possible explanation for such results is that omnipresent economic crisis forced state owned companies to strengthen their costs and revenues control in order to achieve positive financial results and reduce budget deficit.

Table 4. Association between form of ownership and derivatives usage

\begin{tabular}{|c|c|c|}
\hline Form of ownership & Derivatives users & Derivatives non-users \\
\hline Private & $25.0 \%$ & $75.0 \%$ \\
\hline State/community & $66.7 \%$ & $33.3 \%$ \\
\hline Mixed & $50.0 \%$ & $50.0 \%$ \\
\hline
\end{tabular}

Next, association between origin of capital and derivatives usage was examined under the assumption that companies established as subsidiaries of foreign companies use derivatives to a greater extent as a result of acquiring new knowledge and expertise from abroad. Results are given in Table 5. Results show that foreign companies use derivatives 
to a larger extent than domestic companies, as was expected. However, derivatives are mostly used by companies of mixed origin of capital. Further research is needed in order to explain such results.

Table 5. Association between origin of capital and derivatives usage

\begin{tabular}{|c|c|c|}
\hline Origin of capital & Derivatives users & Derivatives non-users \\
\hline Domestic & $21.4 \%$ & $78.6 \%$ \\
\hline Foreign & $40.0 \%$ & $60.0 \%$ \\
\hline Mixed & $66.7 \%$ & $33.3 \%$ \\
\hline
\end{tabular}

Further on, association between income and derivatives usage was examined. According to the income realized in 2011, companies were divided into four groups. Assumptions regarding impact of income are somewhat divided. It can be assumed that companies with higher income use derivatives to a larger extent as they have higher financial exposure to risk. On the other hand, it can be hypothesised that companies with smaller income use derivatives to a larger extend as they are in greater threat of financial distress. Results are presented in Table 6. Results suggest there is no consistent impact of income on derivatives usage. Somewhat similar shares of companies of all income classes use derivatives, with the exception of companies in the 500 million to 1 billion HRK income class that are using derivatives to a considerably smaller extent. Such results can be explained by the fact that all surveyed companies are large companies. Perhaps, income impact would have been more pronounced if companies of different sizes were examined.

Table 6. Association between income and derivatives usage

\begin{tabular}{|c|c|c|}
\hline Income & Derivatives users & Derivatives non-users \\
\hline Less than 100 million HRK & $33.3 \%$ & $66.7 \%$ \\
\hline 100 to 500 million HRK & $37.5 \%$ & $62.5 \%$ \\
\hline 500 million to 1 billion HRK & $14.3 \%$ & $85.7 \%$ \\
\hline More than 1 billion HRK & $33.3 \%$ & $66.7 \%$ \\
\hline
\end{tabular}

Last, association between education and derivatives usage was examined. It was assumed that education has positive impact on derivatives usage, i.e. that the companies with higher share of top managers with university degree use derivatives to a larger extent. Such assumption is reasonable given that results show that formal faculty education is primary source of information about derivatives for majority of respondents. Results on impact of education are given in Table 7. Results show that education has positive, but inconsistent, effect on derivatives usage. The higher the share of top managers with university degree the higher is the share of companies that use derivatives, with the exception of companies with 50 to $80 \%$ of top managers with university degree.

Table 7. Association between education and derivatives usage

\begin{tabular}{|c|c|c|}
\hline $\begin{array}{c}\text { Share of top managers with } \\
\text { university degree }\end{array}$ & Derivatives users & Derivatives non-users \\
\hline Less than $50 \%$ & $16.7 \%$ & $83.3 \%$ \\
\hline 50 to $80 \%$ & $0.0 \%$ & $100.0 \%$ \\
\hline More than $80 \%$ & $50.0 \%$ & $50.0 \%$ \\
\hline
\end{tabular}

\section{Conclusion}

Active risk management is an important part of contemporary corporate financial culture and growing use of derivatives is a result of increased awareness of potential benefits of proper risk management among corporate managers. However, the results of an empirical survey study show that majority of large Croatian companies are only moderately familiar with the derivatives and trading strategies on derivatives market. Herein, hedging comes to the fore as a trading strategy that large Croatian companies are most familiar with. The dominant source of information about derivatives is formal university education followed by education at workplace.

Only $21.9 \%$ of surveyed companies use derivatives, mainly over-the counter forward contracts on foreign currency with the basic purpose of hedging against unfavorable foreign exchange and commodity price movements. Furthermore, 
the results show that hedging is perceived as the most important derivatives trading strategy for company profitability, as well as the one the usage of which results with greatest benefits. Accordingly, large Croatian companies can be characterized as highly risk aversive.

As the most important obstacles to more widespread use of derivatives among large Croatian companies following can be featured: insufficient knowledge about derivatives market and trading strategies; perception of derivatives as highly risky form of investment and lack of awareness and initiative by the companies' top management. According to the survey results, it can be concluded that further education among Croatian companies is needed, both on the benefits and risks of derivatives usage. By avoiding trading at derivatives market companies are missing on business opportunities, therefore promotion of derivatives among company managers is necessary as well.

Regarding the impact of company characteristics on usage of derivatives, results show that economic sector, legal organizational form, educational structure, form of ownership and origin of capital are associated with derivatives usage. Companies engaged in activities from primary economic sector, organized as public limited company and with larger share of top manager with university education tend to use derivatives to a greater extent. Results on the impact of form of ownership and origin of capital are somewhat surprising as they show that companies owned by state and companies with joint domestic and foreign origin of capital tend to use derivatives to a greater extent. On the other hand, income proves not to have an impact on derivatives usage.

As limiting factor of this study, sample size should be mentioned. A sample size of 32 companies is too small for more comprehensive statistical analysis. Future researches should try to include larger number of companies and companies of different sizes as to provide further insights into impact of company characteristics on derivatives usage. The value of conducted research is that it offers preliminary insights into impact of company characteristics on derivatives usage among Croatian companies.

\section{References}

Afza, T. \& Alam, A. (2011). Corporate derivatives and foreign exchange risk management: A case study of non-financial firms of Pakistan, The Journal of Risk Finance, 12 (5), pp. 409-420

Alkebäck, P., Hagelin, N. \& Pramborg, B. (2006) Derivative usage by non-financial firms in Sweden 1996 and 2003: what has changed?, Managerial Finance, 32 (2), pp. 101-114

Baković, T., Štulec, I. \& Mirković, J. (2012) Primjena terminske trgovine među hrvatskim poduzećima, Proceedings of 3rd International Conference "Vallis Aurea" focus on: Regional Development, Polytechnic of Požega, Croatia \& DAAAM International Vienna, Austria, pp. $41-49$

Bartram, S.M. (2000) Corporate risk management as a lever for shareholder value creation, Financial markets, institutions and instruments, 9 (5), pp. 279-324

Bodnar, G.M., de Jang, A. \& Macrae, V. (2003) The Impact of Institutional Differences on Derivatives Usage: a Comparative Study of US and Dutch Firms, European Financial Management, 9 (3),pp. 271-297

Bodnar, G.M., Hayt, G.S. \& Marston, R.C. (1998) 1998 Survey of financial risk management by US non-financial firms, Financial Management, 27, pp. 70-91

Božić, M. (2010) Određivanje cijena opcija na futures ugovore za poljoprivredne proizvode: utjecaj vremenskih uvjeta i zaliha, Radni materijali Ekonomskog instituta Zagreb, 3, pp. 5-33

De Ceuster, M.J.K., Durinck, E., Laveren, E. \& Lodewyckx, J. (2000) A survey into the use of derivatives by large non-financial firms operating in Belgium, European Financial Management, 6 (3), pp. 301-318

Dedi, L. (2004) Mogućnosti primjene geometrijskog Brownovog gibanja za vrednovanje opcija, Ekonomski pregled, 55 (11-12), pp. 1002-1017

El-Masry, A.A. (2006) Derivatives use and risk management practices by UK nonfinancial companies, Managerial Finance, 32 (2), pp. $137-159$

Gardijan, M. (2011) Strategije trgovanja opcijama, Ekonomski pregled, 62 (5-6), pp. 311-337

Grant, K. \& Marshall, A.P. (1997) Large UK Companies and derivatives, European Financial Management, 3 (2), 191-208

Heaney, R. \& Winata, H. (2005) Use of derivatives by Australian companies, Pacific-Basin Finance Journal, 13, pp. 411 - 430

Jalilvand, A., Switzer, J. \& Tang, C. (2000) A global perspective on the use of derivatives for corporate risk management decisions, Managerial Finance, 26 (3), pp. 28-38

Kolb, R.W. (2003) Futures, options and swaps, Oxford: Blachwell Publishing

Lazibat, T. \& Baković, T. (2007) Hedging opcija kao sredstvo eliminacije rizika cijene, Ekonomska misao i praksa, 16 (1), pp. 63-78

Lazibat, T. \& Matić, B. (2001) Strategije trgovanja opcijama na terminskom tržištu, Ekonomski pregled, 52 (11-12), pp. 63-78

Lazibat, T. (2000) Prednosti trgovanja opcijama na terminske ugovore u odnosu na direktno trgovanje terminskim ugovorima, Ekonomski pregled, 51 (5-6), pp. 509-519

Lazibat, T., Brizar, B. \& Baković, T. (2007) Burzovno poslovanje - terminska trgovina, Zagreb: Znanstvena knjiga 
Lazibat, T., Štulec, I. \& Baković, T. (2011) Specifičnosti trgovanja vremenskim izvedenicama ovisno o organiziranosti terminskog tř̌išta, Zbornik Ekonomskog fakulteta u Zagrebu, 9 (1), pp. 1-16

Lazibat, T., Županić, I. \& Baković, T. (2009) Vremenske izvedenice kao instrumenti terminskog tržišta, Ekonomska misao i praksa, 18 (1), pp. 59-81

Miloš Sprčić, D. \& Šević, Ž. (2008) Comparative Analysis of Corporate Risk Management Practices in Croatian and Slovenian Companies, Zagreb International Review of Economics \& Business, 11 (2), pp. 63-80

Miloš Sprčić, D. (2007a) Corporate Risk Management Rationales: Evidence from Croatian Companies, Ekonomski pregled, 58 (9-10), pp. 497-521

Miloš Sprčić, D. (2007b) Izvedenice kao instrument upravljanja financijskim rizicima: primjer hrvatskih i slovenskih nefinancijskih poduzeća, Financijska teorija i praksa, 4, pp. 387-413

Miloš Sprčić, D., Tekavčić, M. \& Šević, Ž. (2008) Corporate Risk Management Practices in Croatian Companies, Ekonomski pregled, 59 (7-8), pp. 344-369

Mseddi, S. \& Abid, F. (2010) Corporate hedging strategy and firm value, International Research Journal of Finance and Economics, 44, pp. 105-128

Narodne novine, no. 109/2007. Zakon o računovodstvu (Official Gazette of the Republic of Croatia)

Nguyen, H. \& Faff, R. (2002) On The Determinants of Derivative Usage by Australian Companies, Australian Journal of Management, 27 (1), pp. 1-24

Orsag, S. (2006) Izvedenice, Zagreb: HUFA

Posedel, P. (2006) Analiza tečaja i vrednovanje opcija na tečaj na hrvatskom tržištu: NGARCH model kao alternativa modelu Blacka i Scholesa, Financijska teorija i praksa, 30 (4), pp. 345-367

Schultz, R. (1996) Rethinking Risk Management, Journal of Applied Corporate Finance, 9 (3), pp. 8-24

Shu, P-G. \& Chen, H-C. (2003) The Determinants of Derivatives Use: Evidence from Non-Financial Firms in Taiwan, Review of Pacific Basin Financial Markets and Policies, 6 (4), pp. 473-500

Slakoper, Z. \& Štajfer, J. (2007) Temeljna obilježja opcijskih ugovora, Zbornik Pravnog fakulteta u Zagrebu, 57 (1), pp. 61-95

Sučić J.H., Miloš Sprčić, D. \& Zoričić, D. (2011) Upravljanje financijskim rizicima u hrvatskim poduzećima, Zbornik Ekonomskog fakulteta u Zagrebu, 9 (1), pp. 67-84

Šperanda, I. (2008) Mogućnosti primjene tehnika terminskog trgovanja na području turizma, Poslovna izvrsnost, 2 (2), pp. 135-149

Šperanda, I. (2009) Uloga hedginga (terminskog tř̌išta) u procesu globalizacije, Poslovna izvrsnost, 3 (1), pp. 161-175

Uran, V. (2007) Princip izvođenja opcija na tř̌ištu električne energije, Energija, 56 (1), pp. 114-133 